\title{
SOURCE ROCK EVALUATION AND BASIN MODELLING OF THE CRETACEOUS SUCCESSION AT QARUN AREA, NORTH WESTERN DESERT, EGYPT
}

\author{
Lotfy, M. M. \\ Exploration Department, Egyptian Petroleum Research Institute (EPRI), 1 Ahmed El Zommor st. Nasr \\ City, Cairo 11727, Egypt; E- mail address: mostafa_lotfy61@ yahoo.com
}

\begin{abstract}
ABSTRAT
The aim of this work provides a better understand of the generation, migration, accumulation of hydrocarbons and multivariable processes that occur during the long basin history by the application of petroleum system modelling. Applying basin modelling makes it possible to evaluate the four dimensional controls on source, reservoir and seal rocks distribution, the master tectonic mechanism, as well as, source rock maturation, migration and trap formation. Petroleum potential therefore is influenced not only by the complex distribution of source, seal and reservoir rocks, but also by the effects of burial, uplift and erosion, which all undergo rapid variations in time and space. With the results of the 1-D basin modelling, a zone favorable for the generation of hydrocarbon from the proposed source rocks was defined based on the deposition and the thickness of the overburden rocks and the timing of the generation and migration of the generated and expelled amounts of petroleum. The evaluation of the results of vitrinite reflectance measurements for two wells in the studied basin was performed to obtain calibration data for 1-D basin modelling. In this context, the influence of temperature on organic matter had to be evaluated; maturity data also allowed calculating paleo-temperatures for the time of maximum burial or maximum temperatures. The result of the 1-D simulation shows the difference in burial, thermal and maturity history for the principle tectonic events.
\end{abstract}

Keywords: TOC; Qarun field; pyrolysis; Maturity; and Basin modeling.

\section{INTRUDUCTION}

The study area lies in the northeastern part of the Qarun lake protected area; it is delineated by latitudes $29^{\circ} 48^{\prime} 13^{\prime \prime}$ and $29^{\circ} 32^{\prime} 12^{\prime \prime}$ to the north, and longitudes $30^{\circ} 33^{\prime} 05^{\prime \prime}$ and $30^{\circ} 45^{\prime} 06^{\prime \prime}$ to the east (Fig. 1). The Qarun acreage had been explored by the Royal Dutch/shell, Amoco and Braspetro. Exploration drilling since 1994 has resulted in six new Egyptian field discoveries, four of which are currently producing approximately 40,000 BOPD. Primary production is from the Cretaceous Bahariya and Kharita sandstone reservoir, as is typical in the Western Desert. The Qarun Field is emerging as the largest and most prolific oil field in the Western Desert, lies on the southeast flank of the Kattaniya uplift and the northwest flank of the Cenozoic Gindi Basin $80 \mathrm{~km}$ southwest of Cairo. The Kattaniya uplift is an inverted Mesozoic basin containing thick Middle Jurassic Khatatba oil-prone source rocks. The oil migrated southeastward to charge Qarun field along a NE-SW trending intrabasinal paleo arch, separating the Kattaniya inverted basin from the Gindi basin.

The sedimentary section in the Northern Western Desert is thick and includes a complete stratigraphic section represented by Paleozoic to Recent sedimentary rocks overlies the Precambrian crystalline basement (Fig. 2). The sedimentary section in the Qarun Field province is characterized by the absence of the Paleozoic and Jurassic rocks Abd El Aziz et al. (1998).

Cretaceous sediments represent the Western Desert's second major transgressive Mesozoic cycle, which occurred after a period of up-lift and erosion that prevailed in the late Jurassic and Early Cretaceous Fawzy and Dahi (1992). The Lower Cretaceous is divided into three main formations, Alam El Bueib, Alamein and Kharita that are mainly of continental environment, while the Upper Cretaceous is also divided into three formations: Bahariya, Abu Roash, and Khoman, which are mainly of shallow marine to open marine environment. Lower Cretaceous section presented in the study wells by Kharita 


\section{Lotfy, M. M.}

Formation, which composed of massive quartzose sandstone interbedded with shales and siltstone, the drilling reaches to Kharita Formation only in El Sagha-1A well at depth of about 2700m.The Upper Cretaceous basins are represented by The Cenomanian Bahariya Formation consists mainly of fine- to medium- grained quartizitic sandstone with thin streaks of shales, and carbonate inclusions Soliman and El Badry (1980). Abu Roash Formation is subdivided into seven members from bottom to top (G, F, E, $\mathrm{D}, \mathrm{C}, \mathrm{B}, \mathrm{A}$ ). The members $\mathrm{A}, \mathrm{C}, \mathrm{E}$, and $\mathrm{G}$ are mainly fine clastics, while those of $\mathrm{B}, \mathrm{D}$, and $\mathrm{F}$ are clean carbonates El Gezeery and O’ Connor (1975).

The source rocks and hydrocarbons potentialities of the Qarune oil field were studied by many authors as: Shahin and Shehab (1988), Abd El Aziz et al (1998), Hammad et al (2010). This is work concerned on the study of source rock evaluation of the Cretaceous sediments and basin modelling at Qarun oil field.

Fig. 1: Location map of the studied wells.
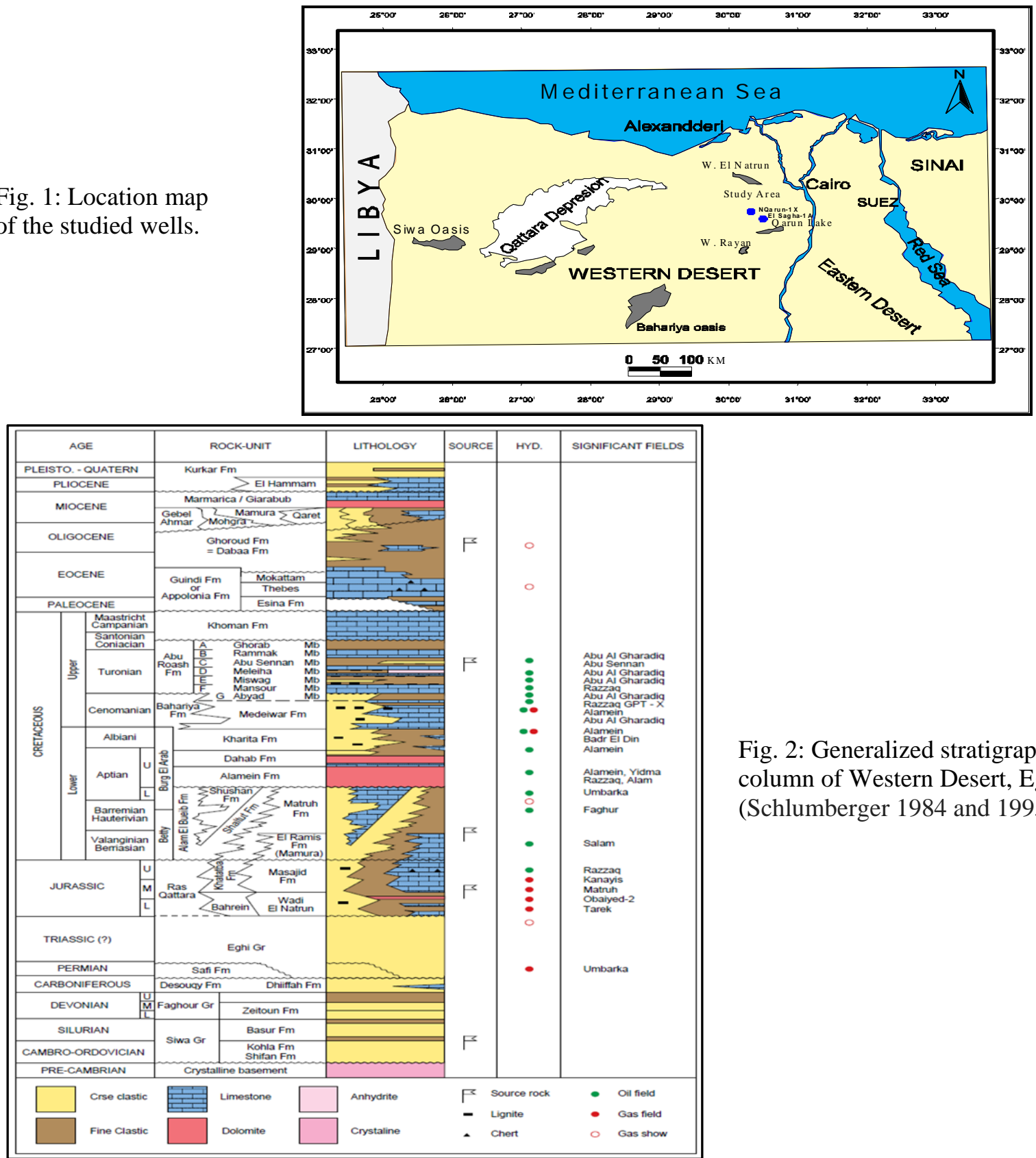

Fig. 2: Generalized stratigraphic column of Western Desert, Egypt (Schlumberger 1984 and 1995). 


\section{Source rock evaluation and basin modelling}

\section{MATERIAL AND METHODS}

Source rocks can be described in terms of their total organic carbon (TOC) content, forty six ditches and cutting samples were analyzed using the LECO SC-632 Analyzer. Estimated minimum TOC values are $0.3 \mathrm{wt} \%$ for carbonates and $0.5 \mathrm{wt} \%$ for shales. The standard pyrolysis method of source rock characterization and evaluation (Rock-Eval), In which the samples which bearing more than $0.5 \%$ wt TOC is progressively heated to $550^{\circ} \mathrm{C}$ under an inert atmosphere, using a special temperature program Espitaile et al. (1977). The result of the analysis is represented by three peaks. The first peak "S1" represent the content of volatile hydrocarbons, which is liberated at temperature less than $200^{\circ} \mathrm{C}$. The second peak "S2" represents the pyroletic hydrocarbons, which is released in temperature range between $300^{\circ}$ and $550^{\circ} \mathrm{C}$. This peak "S2" represents the hydrocarbon that would be generated if burial and maturation continued to completion. The values of the two peaks S1 and S2 are expressed as a ratio of milligrams of hydrocarbons per gram of rock $(\mathrm{mg} / \mathrm{g})$. The third peak "S3" represents the quantity of carbon dioxide (CO2) liberated from the combustion of the organic matter, and it is expressed in milligrams of $\mathrm{CO} 2$ per gram of rock (mg CO2/ gm). Tmax values less than $435{ }^{\circ} \mathrm{C}$ indicate immature organic matter; between 435 and $470{ }^{\circ} \mathrm{C}$, the organic matter is mature; and Tmax values greater than $470{ }^{\circ} \mathrm{C}$ indicate the wet gas zone or post-mature stage (Peters and Cassa, 1994). Vitrinite reflectance (Ro) was measured on kerogen using standard procedures as described in Taylor et al (1998). Basin Modelling has become an important tool in the study of the burial history and thermal evaluation of sedimentary basins. Evaluating the generation, migration and entrapment of hydrocarbons were executed by numerical basin modelling. Basin modelling is the temporal reconstruction of basin history and refers to the procedure of establishing the sequential record of changes in controls and products, which have occurred during the long geologic history of a basin. The 1-D basin simulation software is PetroMod, which used for modeling the petroleum history. The conceptual model is adjusted to lead to a better match between simulation and calibration data (Poelchau et al 1997). The conceptual model includes the concept of the "petroleum system" within the basin model (Magoon and Dow, 1994).

\section{RESULTS AND DISCCUTION}

\section{Source rock evaluation}

Source rock quality is defined by amount and type of kerogen and bitumen as well as its stage of maturity. The oil source capacity depends on evaluation of source rock "which are commonly shales and lime-mudstone contain significant amounts of organic matter (more than, $0.5 \mathrm{or} 0.3 \mathrm{wt} \%$ of the whole rock)". The type of kerogen varies referring to the composition of the original biological matter and the environmental conditions during diagenesis. Generally, lacustrine and marine organic matter (kerogen types I and II) have much higher petroleum potential than terrestrial organic matter (kerogen type III) which predominates on continental shelves, especially in areas influenced by submarine fans (Dow 1977). Geochemical analyses were carried out on the interval $1918 \mathrm{~m}$ to $3470 \mathrm{~m}$ in N Qarun-1x and El Sagha-1A wells of the studying area. As shown in (Table 1). The analyzed section includes rocks ranging in age from Lower Cretaceous (Kharita Formation) to the upper Cretaceous (Bahariya Formation, A/R G member). The organic rich intervals of Abu Roash "G" member assigned to shale sequences that was deposited in a shallow marine environment. The screening analysis TOC and Rock Eval pyrolysis results of the samples revealed the presence of organic source types; The first source type is strongly oilprone and is represented by the limestone in Abu Roash G members (intervals 1918-2218m (Table 1). These rocks are characterized by generally high organic contents (TOC $0.57-2.53 \mathrm{wt} \%$ ) and generally fair to very good potential for oil generation (Type II Kerogen) (pyrolysis S2 yields $0.25-17.23 \mathrm{mg} \mathrm{HC/g}$ rock and HI 34 -718 mg HC/g TOC; Figure 3 A-C).

TOC: Total organic carbon (weight percent of the whole rock) $\mathrm{S}_{1}$ : Low hydrocarbon yield (mg hydrocarbon/g rock). $\mathrm{S}_{2}$ : High hydrocarbon yield (mg hydrocarbon/g rock). HI: Hydrogen index (mg hydrocarbon/g TOC). OI: Oxygen index (mg CO2/g TOC). Tmax: Temperature at which maximum emission of high temperature (S2) hydrocarbon occurs (deg. C) PI: Production index (S1/S1+S2). 
Lotfy, M. M.

Table 1: Pyrolysis data for the Cretaceous sediments of NQarun-1X and El Sagha-1A wells.

\begin{tabular}{|c|c|c|c|c|c|c|c|c|c|c|c|}
\hline $\begin{array}{l}\bar{\Xi} \\
\text { 売 }\end{array}$ & 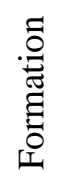 & 苶 & $\bigcup_{0}^{3}{ }^{3}$ & $\begin{array}{l}\frac{00}{000} \\
\Xi \\
\vec{n}\end{array}$ & $\begin{array}{l}\text { on } \\
\text { DD } \\
\Xi \\
\sim \\
\omega\end{array}$ & $\begin{array}{l}\frac{D}{00} \\
\qquad \\
D \\
n \\
n\end{array}$ & 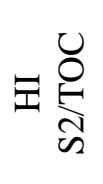 & 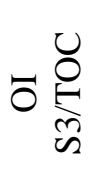 & 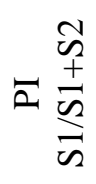 & 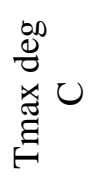 & 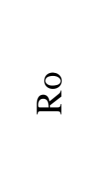 \\
\hline \multirow{8}{*}{ 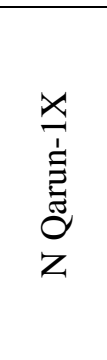 } & \multirow{8}{*}{\begin{tabular}{l}
0 \\
$\mathbb{2}$ \\
\multirow{2}{4}{}
\end{tabular}} & 2094 & 0.88 & 0.13 & 1.22 & 0.98 & 139 & 111 & 0.1 & 430 & 0.37 \\
\hline & & 2115 & 2.07 & 0.29 & 9.76 & 1.27 & 471 & 61 & 0.03 & 422 & 0.5 \\
\hline & & 2118 & 2.08 & 0.5 & 13.2 & 1.05 & 635 & 50 & 0.04 & 419 & 0.25 \\
\hline & & 2136 & 2.4 & 0.85 & 17.23 & 0.96 & 718 & 40 & 0.05 & 418 & \\
\hline & & 2139 & 2.53 & 0.91 & 15.01 & 0.93 & 593 & 37 & 0.06 & 418 & \\
\hline & & 2148 & 1.06 & 0.17 & 2.97 & 0.85 & 280 & 80 & 0.05 & 423 & 1.2 \\
\hline & & 2164 & 0.74 & 0.13 & 0.88 & 0.66 & 119 & 89 & 0.13 & 426 & 0.5 \\
\hline & & 2203 & 0.73 & 0.12 & 1.28 & 0.96 & 175 & 132 & 0.09 & 429 & \\
\hline \multirow{9}{*}{ 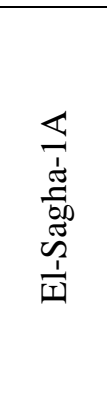 } & \multirow{9}{*}{$\begin{array}{l}u \\
\stackrel{1}{<}\end{array}$} & 1918 & 0.62 & 0.12 & 0.17 & 1.24 & 27 & 200 & 0.41 & 422 & 0.14 \\
\hline & & 1927 & 0.97 & 0.18 & 0.61 & 2.06 & 63 & 212 & 0.23 & 426 & 0.30 \\
\hline & & 1930 & 1.13 & 0.13 & 0.51 & 1.72 & 45 & 152 & 0.2 & 424 & 0.30 \\
\hline & & 1970 & 0.7 & 0.13 & 0.48 & 1.19 & 69 & 170 & 0.21 & 428 & 0.40 \\
\hline & & 2017 & 0.72 & 0.16 & 0.37 & 1.15 & 51 & 160 & 0.3 & 424 & 0.32 \\
\hline & & 2042 & 1.03 & 0.15 & 0.96 & 0.87 & 93 & 84 & 0.14 & 425 & 1.10 \\
\hline & & 2127 & 0.83 & 0.55 & 1.37 & 74 & 165 & 89 & 0.29 & 425 & 0.02 \\
\hline & & 2185 & 0.79 & 0.32 & 0.68 & 0.54 & 86 & 68 & 0.32 & 426 & 1.26 \\
\hline & & 2218 & 0.82 & 0.26 & 1.13 & 0.6 & 138 & 73 & 0.19 & 426 & 1.88 \\
\hline \multirow{5}{*}{ 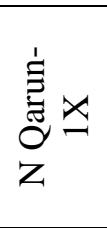 } & \multirow{5}{*}{ 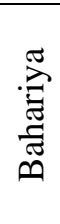 } & 2209 & 0.78 & 0.15 & 1.3 & 0.97 & 167 & 124 & 0.1 & 430 & 1.9 \\
\hline & & 2294 & 0.54 & 0.07 & 0.26 & 1.11 & 48 & 206 & 0.21 & 431 & \\
\hline & & 2306 & 1.22 & 0.17 & 3.5 & 0.91 & 287 & 75 & 0.05 & 427 & 1.5 \\
\hline & & 2330 & 0.88 & 0.13 & 1.53 & 1.1 & 174 & 125 & 0.08 & 427 & \\
\hline & & 2352 & 0.56 & 0.12 & 0.4 & 0.63 & 71 & 113 & 0.23 & 430 & 1.21 \\
\hline \multirow{11}{*}{ 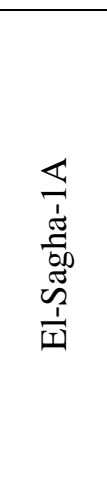 } & \multirow{11}{*}{ 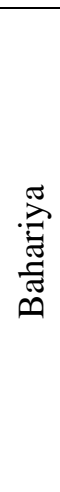 } & 2230 & 0.59 & 0.24 & 0.34 & 0.41 & 58 & 69 & 0.41 & 424 & 0.83 \\
\hline & & 2255 & 0.64 & 0.4 & 0.49 & 0.51 & 77 & 80 & 0.45 & 427 & 0.96 \\
\hline & & 2264 & 0.5 & 0.45 & 0.26 & 0.42 & 52 & 84 & 0.58 & 425 & 0.62 \\
\hline & & 2279 & 0.8 & 0.3 & 0.69 & 0.58 & 86 & 73 & 0.3 & 432 & 1.19 \\
\hline & & 2297 & 0.62 & 0.36 & 0.5 & 0.61 & 81 & 98 & 0.42 & 429 & 0.82 \\
\hline & & 2394 & 0.54 & 0.4 & 0.46 & 0.64 & 85 & 119 & 0.47 & 426 & 0.72 \\
\hline & & 2406 & 0.51 & 0.17 & 0.28 & 0.71 & 55 & 139 & 0.38 & 427 & 0.39 \\
\hline & & 2479 & 0.5 & 0.22 & 0.45 & 0.55 & 90 & 110 & 0.33 & 430 & 0.82 \\
\hline & & 2527 & 0.58 & 0.22 & 0.66 & 0.58 & 114 & 100 & 0.25 & 435 & 1.14 \\
\hline & & 2533 & 0.68 & 0.28 & 0.74 & 0.66 & 109 & 97 & 0.27 & 434 & 1.12 \\
\hline & & 2609 & 0.52 & 0.16 & 0.53 & 0.82 & 102 & 158 & 0.23 & 429 & 0.65 \\
\hline \multirow{4}{*}{ 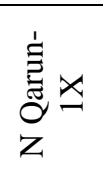 } & \multirow{4}{*}{ 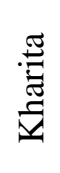 } & 2527 & 0.53 & 0.07 & 0.44 & 0.81 & 83 & 153 & 0.14 & 435 & 0.45 \\
\hline & & 2670 & 0.5 & 0.04 & 0.25 & 0.64 & 50 & 128 & 0.14 & 434 & 0.64 \\
\hline & & 2852 & 0.57 & 0.08 & 0.34 & 0.84 & 60 & 147 & 0.19 & 433 & 1.47 \\
\hline & & 2864 & 0.52 & 0.07 & 0.31 & 0.76 & 60 & 146 & 0.18 & 433 & 0.79 \\
\hline \multirow{8}{*}{$\begin{array}{l}\mathbb{J} \\
\frac{1}{d} \\
\frac{\pi}{00} \\
\tilde{D} \\
\frac{1}{1} \\
\frac{1}{|c|}\end{array}$} & \multirow{8}{*}{ 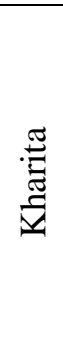 } & 2664 & 0.61 & 0.06 & 0.43 & 0.47 & 70 & 77 & 0.12 & 433 & 0.91 \\
\hline & & 2685 & 0.51 & 0.06 & 0.45 & 0.38 & 88 & 75 & 0.12 & 431 & 1.18 \\
\hline & & 2791 & 0.91 & 0.16 & 0.81 & 1.03 & 89 & 113 & 0.16 & 431 & 0.79 \\
\hline & & 3221 & 1.03 & 0.25 & 0.96 & 0.9 & 93 & 87 & 0.21 & 436 & 1.07 \\
\hline & & 3330 & 1.01 & 0.15 & 1.63 & 0.59 & 161 & 58 & 0.08 & 434 & 2.76 \\
\hline & & 3358 & 0.96 & 0.15 & 1.54 & 2.01 & 160 & 209 & 0.09 & 434 & 0.77 \\
\hline & & 3436 & 1.51 & 0.12 & 1.76 & 0.76 & 117 & 50 & 0.06 & 436 & 2.32 \\
\hline & & 3470 & 0.85 & 0.16 & 0.74 & 0.52 & 87 & 61 & 0.18 & 433 & 1.42 \\
\hline
\end{tabular}


Source rock evaluation and basin modelling

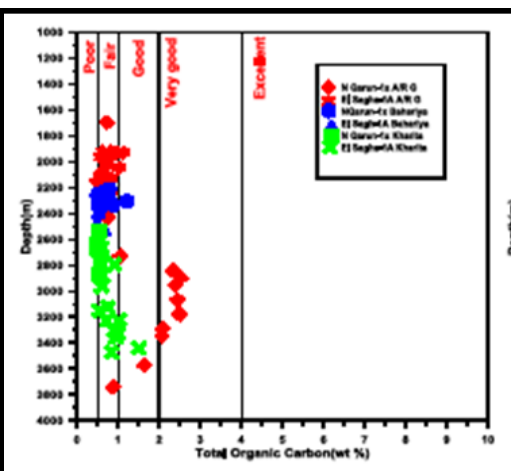

A

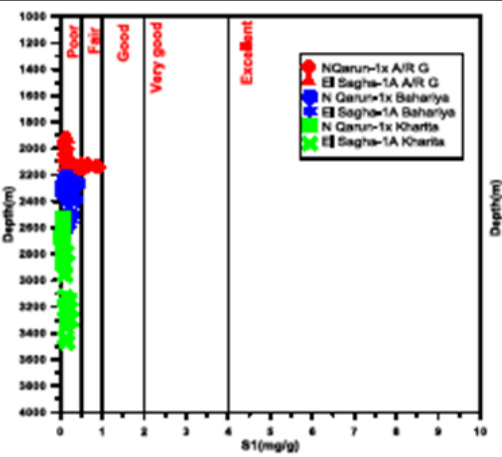

B

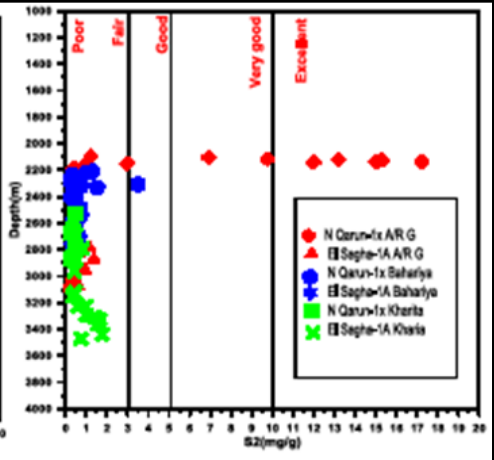

$\mathrm{C}$

Fig. 3: (A-C) Organic Richness of the Cretaceous formations, North Western Desert, Egypt.

The PI increases with maturity as hydrocarbons are generated (Tissot and Welte, 1984). The second source type is mixed oil and gas prone and represented by the intercalated limestones and shales interval 2218-2609m and 2527-3470m in Abu Roash G members, Bahariya and Kharita formations respectively. Bahariya appear to have generally high organic content (TOC 0.5-1.22 wt\%) and good hydrocarbon generating potential (pyrolysis S2 yields 0.29-1.53 mg HC/g TOC; Figure 3 A-C). Most of these rocks have the capacity of generating oil and gas at maturity (Abd El Gawad, et al 2019) (Type II Type III), as indicated from their moderate hydrogen indices (HI 55-174; Figure 4 A-B). Kharita have high organic content (TOC 0.5-1.51 wt \%) and fair hydrocarbon generating potential (pyrolysis S2 yields 0.25-1.176 mg HC/g TOC; Figure 3 A-C). Most of these rocks have the capacity of generating oil and gas at maturity (Type II - Type III), as indicated from their moderate hydrogen indices (HI 50-160; Figure 4 A-B). The plot of S1 versus TOC, showing indigenous hydrocarbons and the Tmax versus PI showing Hydrocarbon Maturation of the Cretaceous Formations (Fig. 4 C\&D).

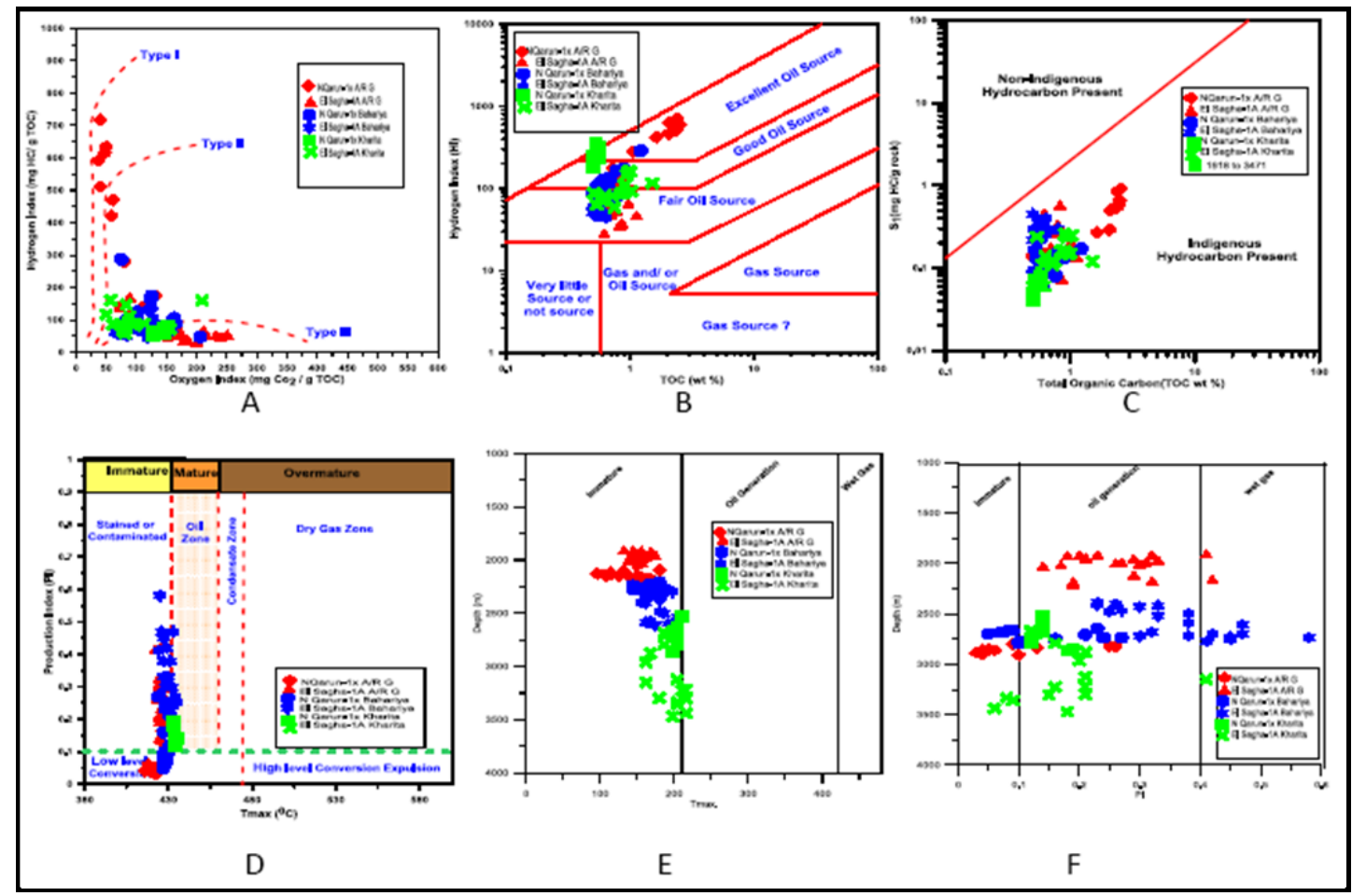

Fig. 4: (A) The modified van Krevelen (HI versus OI) diagram (after Espitalié, et al., 1977), (B) The TOC versus HI diagram showing organic enrichments (after Jackson, et al., 1985), (C) The TOC versus S1 showing indigenous hydrocarbon (Hunt, 1996), (D) The Tmax versus PI diagram (Delvaux et al., 1990), and (E\&F) Hydrocarbon Maturation of the Cretaceous sediments North Western Desert Egypt. 
Lotfy, M. M.

\section{Maturity}

The most widely used thermal maturity indicator is the reflectance of the vitrinite macerals in coal, coaly particles, or dispersed organic matter, which increase as a function of temperature and time from approximately $0.25 \%$ Ro at the peat stage to more than $4.0 \%$ Ro at the met anthracite stage. There is a general increase in vitrinite reflectance with depth as shown in (Table 1, Fig. 4 E\& F). Depending on organic matter composition the maturity profile will reaches to value $\left(0.6 \mathrm{R}_{\mathrm{O}} \%\right)$ at approximately depth $1780 \mathrm{~m}$. Tmax values indicate a higher maturity than that derived from $\mathrm{R}_{0} \%$. Tmax values in Kharita, Lower Bahariya and Upper Bahariya Formations are slightly high. In addition, the maturation trend obtained from pyrolysis Tmax values indicates a lower maturity than that derived from Ro\% and thus, may be due to contamination in some samples (Table 1, Fig. 4 E \& F).

\section{THERMAL HISTORY}

The thermal history of rocks is determined by the boundary condition of surface temperature and the basement heat flow. The temperature at points in between is controlled by the thermal conductivities of the sediments. The boundary conditions of surface temperature and basement heat flow vary through time during the evolution of a sedimentary basin. During the burial of the sediments, their thermal conductivities have altered as the rock compacted. A high heat flow peak has been assumed in the Cretaceous rifting phase is set at $88 \mathrm{~mW} / \mathrm{m}^{2}$. The present day vitrinite reflectance values based on the calculation of Sweeney and Burnham (1990), Show relatively similar values for A/R-G member in the different wells the present- day simulated vitrinite values range is $0.54 \%$ in N Qarun- $1 \mathrm{X}$ wells but $0.55 \%$ in El Sagha- $1 \mathrm{~A}$ well, with temperature range from $65.7^{\circ} \mathrm{C}$ in $\mathrm{N}$ Qarun- $1 \mathrm{X}$ to $70.93^{\circ} \mathrm{C}$ in $\mathrm{El}$ Sagha- 1A (Fig. 5 A \& B).

A
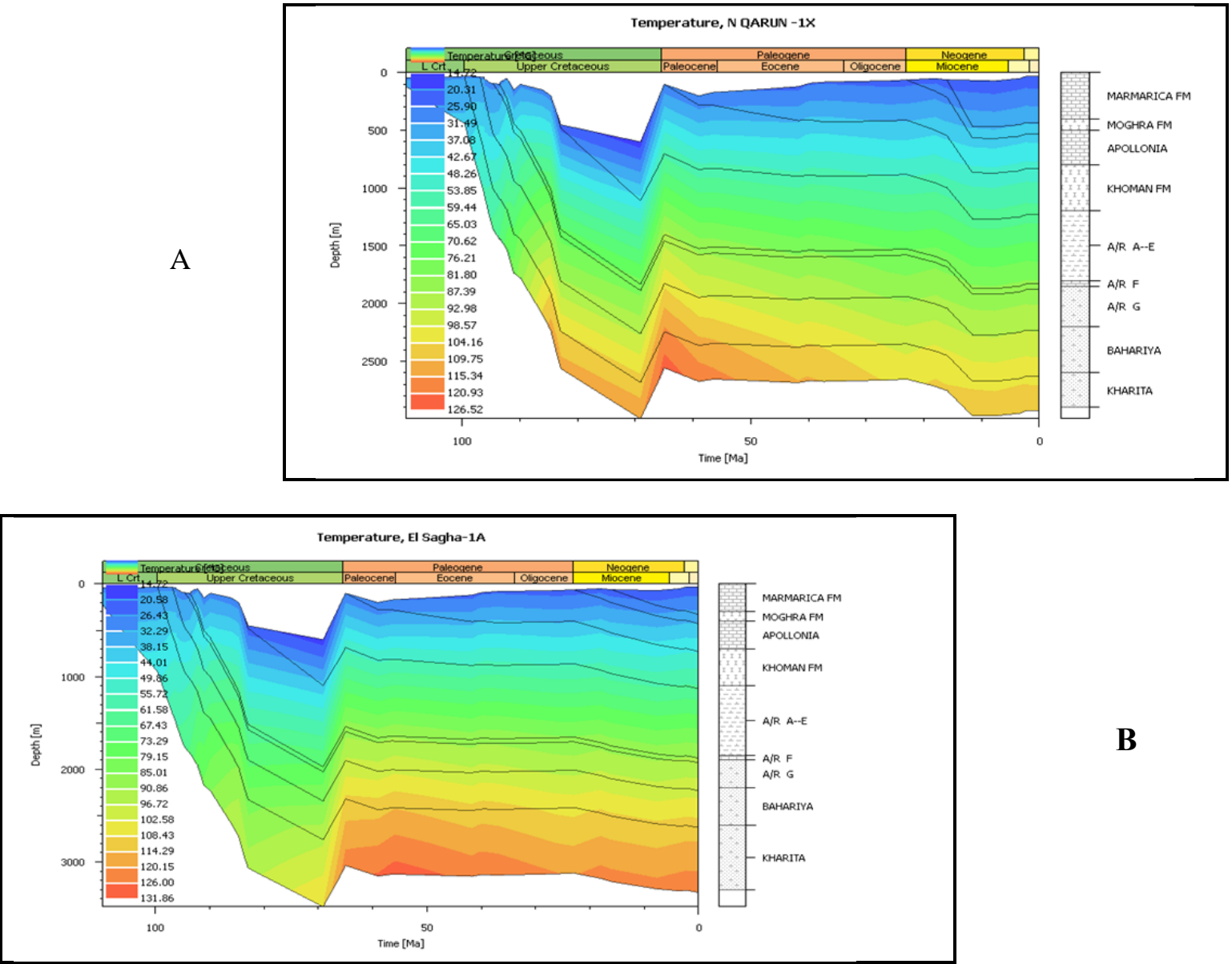

Fig. 5: (A \& B) Modeled burial and thermal histories in NQarun-1X and El Sagh-1A wells. 


\section{Source rock evaluation and basin modelling}

\section{Burial History and Hydrocarbon Zones}

The burial history of Qarun basin is represented by time-depth history plots that show the burial of different horizons traced through time, from deposition to present day. The plots indicate the main features of deposition in the Qarun basin, which represented by five principle phases ranging from Early Cretaceous to the present. The subsidence during the Early Cretaceous ( 112 -101 Mabp) was characterized by a burial rates of about $25 \mathrm{~m}$ per million years, the Kharita formation deposited during this period with up to 290m thick ( 101-99 Mabp). The Late Cretaceous period comprises two phases (phase 2 and 3), Phase 2 which extended from ( 99-88 Mabp) and characterized by very rapid rate of sedimentation of about $72 \mathrm{~m}$ per million year and led to the deposition of Bahariya formation due to marine Cenomanian transgression followed by fully marine transgression during the Upper Cenomanian and Turonian which led to the deposition of Abu Roash formation. Subsidence decreased to $15 \mathrm{~m}$ per million years in Phase 3 ( 84-69 Mabp) led to the deposition of Khoman formation. The fourth phase in Paleocene age from ( 65-59 Mabp) characterized by low sedimentation rate of $17 \mathrm{~m}$ per million years and led to the deposition of Esna formation, which completely eroded later. The last phase in Eocene age characterized by very rapid rate of sedimentation about $93 \mathrm{~m}$ per million years, extended from ( 5740 Mabp), and led to the deposition of Apollonia formation (Figures 6 A\&B). In N Qarun-1X well, A/R$\mathrm{G}$ entered the oil window at ( $34.55 \mathrm{Mabp})$ at depth $2188 \mathrm{~m}$ and reaches its maximum burial depth at $2266 \mathrm{~m}$ and still in oil window, In El Sagh-1A well the oil window began at ( 38.00 Mabp) at depth $2183 \mathrm{~m}$ and reaches its maximum burial depth at 2208m at ( 40.00 Mabp) and now AR-G in El Sagh-1A well still in oil window.
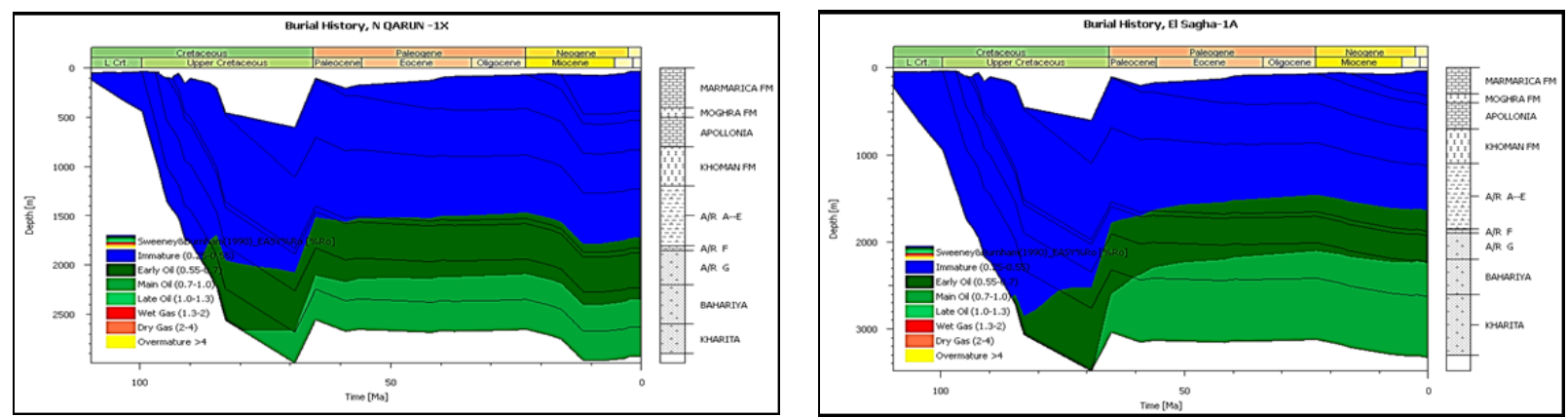

Fig. 6: The Burial history and hydrocarbon zones in N Qarun-1X and El Sagh-1A wells.

\section{CONCLUSIONS}

Qarun Concession is considered one of the most prolific basins in the northern part of the Egyptian Western Desert. A thin Lower Cretaceous section was deposited directly over the Precambrian basement rocks followed by Cenomanian and Turonian sediments overlie these Lower Cretaceous rocks. The source rock analyses of the studied formations by total organic matter content results revealed that, the Abu Abu Roash "G" members have total organic matter and organic carbon content, but they are not potentially enough to produce indigenous oil, this reflects the exogenous nature of the encountered hydrocarbons of these rock units. These TOC values were determined within the main two source rocks, namely, Abu Abu Roash "G" members. Abu Roash "G" member classified into four source intervals dispersed in the wells of the study area All of them consist of shale and have type IIIII organic matter. As well as TOC range from $0.57 \mathrm{wt} \%$ to $2.53 \mathrm{wt} \%$. Bahariya appear to have generally high organic content (TOC 0.5-1.22 wt \%) and generally good hydrocarbon generating potential. Kharita have high organic content (TOC 0.5-1.51 wt \%) and fair hydrocarbon generating potential. Two wells were modeled using the modelling software (PetroMod 1-D).The basin analysis involves reconstructing the thermal and burial histories of the basin and understanding the processes and mechanisms by which it formed. 


\section{REFERENCES}

Abd El Gawad, E. A, Mohamed F.; Ghanem, Lotfy, M. M., Mousa, D. A.; Temraz, M. G., and Shehata, A. M. (2019): Burial and thermal history simulation of the subsurface Paleozoic source rocks in Faghur basin, north Western Desert, Egypt: Implication for hydrocarbon generation and expulsion history, Egypt. J. Petrol., 28, 261-271.

Abd El Aziz, A. L., Moustafa, A. R. and Said, S. E. (1998): Impact of basin inversion on hydrocarbon habitat in the Qarun concession, Western Desert, Egypt. EGPC 14 ${ }^{\text {th }}$ Petrol. Conf. Cairo. 1, 139-156.

Delvaux, D., Martin, H., Leplat, P. and Paulet, J. (1990): Geochemical characterization of sedimentary organic matter by means of pyrolysis kinetic parameters. In: Durand B, Behar F (eds) Advances in Organic Geochemistry. Pergamon, Oxford. Organic Geochemistry, 16, 175-187.

DOW, W.G., (1977): Kerogen studies and geological interpretation. J. Geochem. Explor., 7, 77-99.

El Gezeery, N. H. and O’Connor, T. (1975): Cretaceous rock units of the Western Desert, Egypt. Ann. Meet. Egypt, Geol. Soc., p. 2.

Espitalie, J., La Porte, J. L., Madec, M., Marquis, F., Le Plat, P., Paulet, J. and Boutefeu, A. (1977): Method rapide de caracterisation des roches meres de leur potential petrolier et de leur degre devolution, Rev. Inst. Francais petrol, 32 , 1, 23-42.

Fawzy, A. and Dahi, M. (1992): Regional geology of the Western Desert, Egypt. $1^{\text {st }}$ Inter. Conf., Geol. Arab World, Cairo Univ., 1, 111-159.

Hammad, M.M., Awad, S.A., El Nady, M.M. and Moussa, D.A. (2010): The subsurface geology and source rocks characteristics of some Jurassic area, North and Cretaceous Sequences in the west Qarun area, North Western Desert, Egypt, Ener. Sourc, 32, 1885 - 1898.

Hunt, J. M. (1996). Petroleum geochemical and geology. W.H. Freeman and company, U.S.A, 743.

Jackson, K. S., Hawkins, P. J., and Bennett, A. J. R. (1985): Regional facies and geochemical evaluation of southern Denison Trough. APEA J. 20, 143-158.

Magoon, L. B., and W. G. Dow, eds., (1994): the petroleum system-from source to trap: American Association of Petroleum Geologists Memoir, (60): Tulsa, Oklahoma, American Association of Petroleum Geologists, 665 p.

Kenneth, P. and Rose Cassa, M. (1994): Applied Source Rock Geochemistry, 60p JO - AAPG Memoir.

Poelchau, H. S., D. R. Baker, T. Hantschel, B. Horsfield, and B. P. Wygrala, (1997): Basin simulation and the design of the conceptual basin model, in H. D. Welte, Horsfield, B., Baker, and D. R., ed., Petroleum and basin evolution: insights form petroleum geochemistry, geology and basin modeling: Berlin, Springer-Verlag, 535.

Schlumberger (1984): Well evaluation conf.: Cairo, Egypt, p 243.

Schlumberger (1995): Well evaluation conf.: Cairo, Egypt, 8-10 April (1995), 87.

Shahin, A.N. and Shehab, M.M. (1988): Undiscovered hydrocarbon reserves and their preservation time limits in west Qarun area, Abu Gharadig basin, Western Desert, Egypt. EGPC $9^{\text {th }}$ Petrol. Explor. Prod. Conf. Cairo, Egypt, 20-30.

Soliman, M. S. and El Badry, O. (1980) : Nature of Cretaceous sedimentation in Western Desert, Egypt, AAPG Bull., 34, 12, 2349-2370.

Sweeney, J. J., and K. A. Burnham, (1990): Evaluation of a simple model of Vitrinite reflectance based on chemical kinetics: AAPG Bull., 74, 1559-1570.

Taylor, G. H., Teichmuller, M., Davis, A., Diessel, C. F. K., Littke, R. and Robert, P. (1998): Organic petrology. Gebr. Borntraeger, Stuttgart, 704 p.

Tissot, B. P. and Welte, D. H. (1984): Petroleum formation and occurrence. Springer-Verlag, Berlin, 699 p.

Waples, D. W, Kamata, H., Suizu, M., (1992): The art of maturity modeling, part 1: finding a satisfactory geologic model. AAPG Bull., 76, 31-46. 
Source rock evaluation and basin modelling

تقييم صخور المصدر ونمذجة حوض تتابع الطباشيري في منطقة قارون ، شمال الصحراء الغربية ، مصر

$$
\begin{aligned}
& \text { مصطفى محمود أمين لطفى } \\
& \text { معهد بحوث البترول المصرى } \\
& \text { ا شارع حسين ذاكر ، حى الزهور ، مدينة نصر بهرب ليترول }
\end{aligned}
$$

\section{الخلاصة}

الهدف من هذا البحث هو توفير فهم جيد لتوليد وهجرة وتراكم الهيدروكربونات المنعددة والمتغيرات التي تحدث خلال تاريخ الحوض الطويل من خلال تطبيق ندذة نظام البترول ـ وتحديد إمكانات نولد الهيدروكربونات من المواد العضوية التي تتواجد

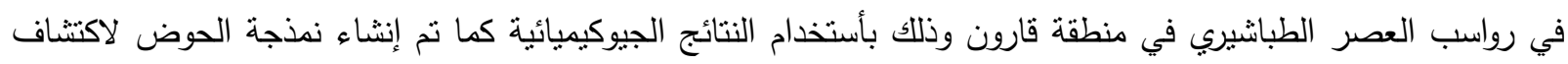
تاريخ الدفن وتقييم صخور المصدر ونمذجة الحوض بأستخدام D1 بترومود للحصول على فهم جيد لاتجاه الهجرة وخريطة

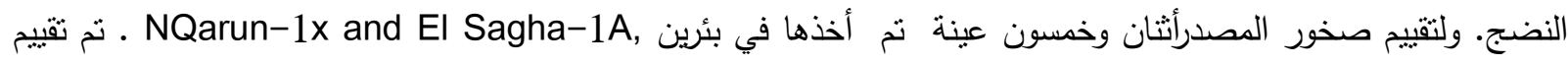

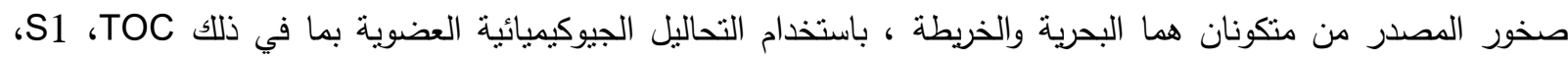

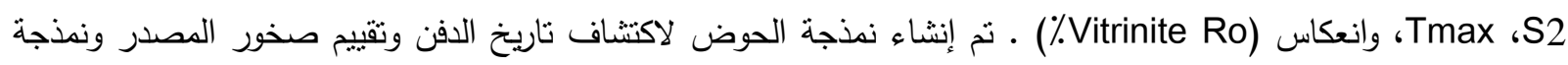
الحوض بأستخدام D بترومود للحصول على فهم جيد لاتجاه الهجرة وخريطة النضج.من خلال نطبيق نمذجة نظام البترول

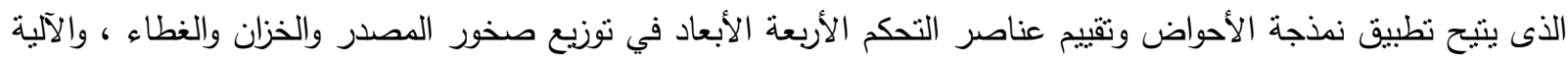

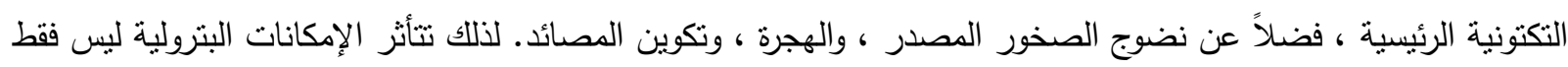

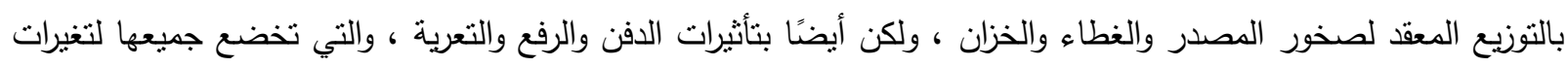

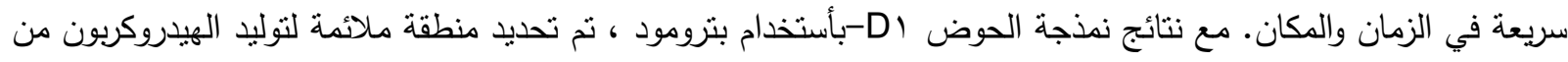

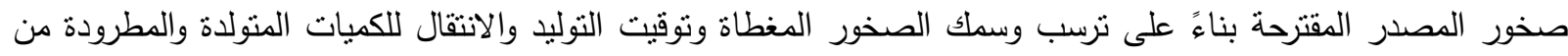

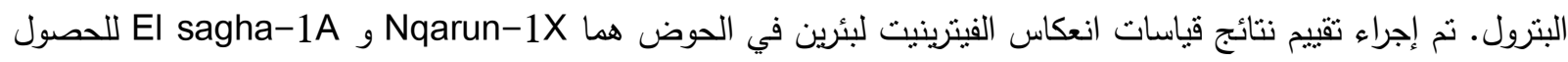

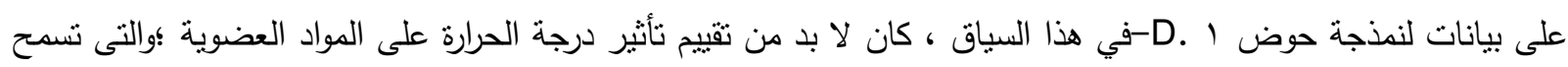

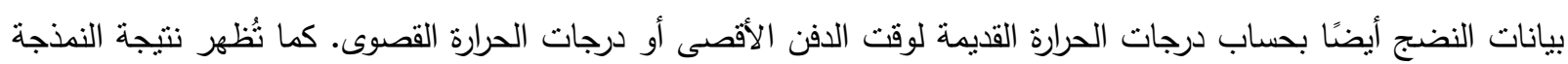
-D الاختلاف في ناريخ الدفن والحرارة والنضج للأحداث التكتونية الرئيسية. 